\title{
Kualitas Sistem Informasi Berdasarkan ISO/IEC 25010: Literature Review
}

\author{
Made Dwi Mulyawan ${ }^{1}$, I Nyoman Satya Kumara ${ }^{2}$, Ida Bagus Alit Swamardika ${ }^{3}$, Komang Oka Saputra ${ }^{4}$ \\ [Submission: 04-06-2020, Accepted: 18-02-2021]
}

\begin{abstract}
Current information systems have become an important part of improving the effectiveness and efficiency of a business process, so we need a measurement of the quality of the software to determine the extent to which the system can produce quality information. In measuring quality, several models can be used as a guide in assessing software. ISO/IEC 25010 is one of the quality models that can be used as a standard in measuring software quality. ISO/IEC 25010 consists of the software product quality model and quality in use model. This article reviews some of the literature that discusses the measurement of software quality using the ISO/IEC 25010 model. Currently, the ISO/IEC 25010 has been applied to assess the quality of academic information systems, government information systems and private institutions, games, mobile applications, and decision support systems. The results of software quality assessment can be determined through the measurement of important aspects chosen based on the needs of each software. Besides the way the testing and data collection used in the assessment can affect the level of accuracy of software quality measurements.
\end{abstract}

Keywords - Software Quality, Quality Model, ISO/IEC 25010, Quality in Use, Software Product Quality.

Intisari- Sistem informasi saat ini telah menjadi bagian penting dalam meningkatkan efektifitas dan efisiensi suatu proses bisnis, sehingga diperlukan suatu pengukuran kualitas perangkat lunak untuk mengetahui sejauh mana sistem dapat menghasilkan informasi yang berkualitas. Dalam melakukan pengukuran kualitas ada beberapa model yang dapat digunakan sebagai panduan dalam melakukan penilaian perangkat lunak. ISO/IEC 25010 merupakan salah satu model kualitas yang dapat digunakan sebagai standar dalam melakukan pengukuran kualitas perangkat lunak. ISO/IEC 25010 terdiri dari software product quality model dan quality in use model. Artikel ini menelaah beberapa literature yang membahas mengenai pengukuran kualitas perangkat lunak yang menggunakan model ISO/IEC 25010. Saat ini ISO/IEC 25010 telah diterapkan untuk menilai kualitas pada sistem informasi akademik, sistem informasi pemerintah dan lembaga swasta, game, mobile application, dan decision support system. Hasil dari penilaian kualitas perangkat lunak dapat ditentukan melalui pengukuran terhadap aspek penting yang dipilih berdasarkan kebutuhan dari setiap perangkat lunak. Selain itu cara pengujian dan pengumpulan data yang digunakan dalam penilaian dapat berpengaruh terhadap tingkat akurasi dari pengukuran kualitas perangkat lunak.

Kata Kunci - Kualitas Perangkat Lunak, Model Kualitas, ISO/IEC 25010, Kualitas Kegunaan, Kualitas Produk Perangkat Lunak.

${ }^{1}$ Mahasiswa, Magister Teknik Elektro Universitas Udayana, Gedung Pacasarjana Universitas Udayana Jl. PB Sudirman Denpasar-Bali, Kode Pos: 80232; (tlp/fax: 0361-239599; e-mail: dwi.mulyawan@student.unud.ac.id)

2, 3, ${ }^{4}$ Dosen, Magister Teknik Elektro Universitas Udayana, Gedung Pacasarjana Universitas Udayana Jl. PB Sudirman Denpasar-Bali, Kode Pos: 80232; (tlp/fax: 0361-239599)

Made Dwi Mulyawan: Pengukuran Kualitas Sistem Informasi...

\section{Pendahuluan}

Sistem informasi merupakan sekumpulan komponen yang mengintegrasikan proses dalam pengumpulan, penyimpanan dan pengolahan data untuk menghasilkan suatu informasi dan pengetahuan [1]. Saat ini sistem informasi telah menjadi peran penting dalam meningkatkan efisiensi dan efektifitas proses bisnis pada suatu perusahaan. Pemanfaatan sistem informasi membantu perusahaan dalam melakukan proses bisnis yang lebih kompetitif, dimana sistem informasi dapat memberikan manfaat dan menghasilkan suatu informasi yang memiliki nilai dalam meningkatkan bisnis.

Dalam melakukan perancangan sistem informasi seorang developer dapat melakukan analisis kebutuhan bisnis dari suatu perusahaan atau instansi untuk mencapai tujuan mereka. Menurut Simanungkalit dkk (2014), dalam melakukan perancangan sistem, acuan dalam menentukan sistem tersebut telah baik dan efektif untuk digunakan yaitu sistem yang dapat menghasilkan umpan balik yang positif dan memiliki fungsi yang sesuai dengan harapan pengguna [2]. Sehingga dalam hal ini diperlukan penggunaan standar kualitas sebagai acuan dalam melakukan perancangan sistem informasi agar dapat menghasilkan sistem yang berkualitas.

Kualitas suatu sistem dapat diukur dari sejauh mana sistem dapat memenuhi kebutuhan yang direpresentasikan dalam model kualitas. Model kualitas adalah landasan dari sistem evaluasi kualitas produk. Model kualitas menentukan karakteristik kualitas mana yang akan dipertimbangkan ketika mengevaluasi sifat-sifat produk perangkat lunak. Kualitas suatu sistem dapat diukur degan melihat sejauh mana sistem dapat memenuhi kebutuhan yang direpresentasikan dalam model kualitas dan mengkategorikan kualitas produk ke dalam karakteristik dan sub karakteristik [3].

Model kualitas menentukan karakteristik kualitas yang akan dipertimbangkan ketika mengevaluasi aspek-aspek produk perangkat lunak. Miguel dkk (2014) menyatakan bahwa model McCall memiliki 11 aspek yang dapat digunakan dalam mengukur kualitas perangkat lunak. Selain model McCall, model kualitas lainnya seperti Boehm, Dromey, FURPS, Ghezzi dan Kazman juga dapat digunakan untuk mengukur kualitas perangkat lunak dari berbagai aspek dan atribut. Sedangkan standar kualitas seperti ISO/IEC membagi aspek kualitas perangkat lunak menjadi beberapa karakteristik dan sub karakteristik [5]. Berdasarkan penelitan yang dilakukan oleh Suman dan Wadhwa (2014) menyatakan bahwa dari perbandingan karakteristik pada setiap model menunjukkan bahwa ISO/IEC 25010 memiliki seluruh karakteristik yang dibutuhkan dalam menentukan kualitas suatu sistem dibandingkan dengan model lainnya [6].

p-ISSN:1693 - 2951; e-ISSN: 2503-2372 
Sehingga penggunaan ISO/IEC 25010 sangat direkomendasikan sebagai panduan dalam perancangan suatu perangkat lunak.

Model kualitas ISO/IEC 25010 merupakan model baru dari seri ISO/IEC 250n yang dikenal sebagai persyaratan dan evaluasi kualitas perangkat lunak SQuaRE. ISO/IEC 25010 memiliki dua jenis model, yakni quality in use model dan software product quality model. Kedua model ini dapat digunakan dalam melakukan pengukuran kualitas suatu perangkat lunak dengan menggunakan karakteristik dan sub karakteristik pada masing-masing model kualitas tersebut. Disamping penggunaan model ISO/IEC 25010, terdapat metode yang juga digunakan sebagai metode pendukung dalam meningkatkan akurasi dalam menilai kualitas perangkat lunak, seperti Goal Question Metrics (GQM), Analytical Hierarchy Process (AHP), dan Fuzzy Logic.

Saat ini penerapan ISO/IEC 25010 dalam pengukuran kualitas perangkat lunak sudah cukup populer. Khususnya di Indonesia telah banyak peneliti yang menggunakan model kualitas ini untuk menilai kualitas sistem informasi yang digunakan pada instansi pemerintah, lembaga swasta, dan perguruan tinggi negeri/swasta. Penggunaan ISO/IEC 25010 dalam perancangan suatu perangkat lunak juga telah banyak dilakukan untuk menghasilkan perangkat lunak atau sistem yang berkualitas. Penggunaan model ini juga dapat membantu untuk memberikan rekomendasi kepada evaluator dalam melakukan peningkatan kualitas perangkat lunak yang digunakan.

Artikel ini mencoba menelaah literatur yang membahas pengukuran kualitas perangkat lunak berdasarkan aspek-aspek kualitas sesuai ISO/IEC 25010. Hasil dari telaah ini diharapkan dapat membantu peneliti dan pengembang sistem informasi serta pemakai sistem informasi untuk mengetahui perkembangan ISO/IEC 25010 sebagai salah satu alat ukur untuk menilai unjuk kerja sebuah sistem informasi.

Sistematika penyajian artikel ini adalah sebagai berikut: Bagian 2 memberikan tinjauan singkat mengenai kualitas sistem informasi dan model kualitas ISO/IEC 25010. Bagian 3 menjelaskan mengenai metode dan bahan yang digambarkan melalui skematik penelitian. Bagian 4 membahas status penelitian terkait penggunaan model ISO/IEC 25010 khususnya penelitian yang dilakukan oleh atau berlokasi di Indonesia, dan garis besar rencana penelitian kedepan.

\section{KUALITAS SISTEM INFORMASI}

\section{A. Kualitas Sistem Informasi}

Kualitas sistem informasi adalah pengukuran proses sistem yang berfokus pada hasil interaksi antara pengguna dan sistem. Kualitas sistem informasi dapat diartikan sebagai fitur yang dapat dilihat dari karakteristik sistem yang berkontribusi pada penyampaian manfaat yang diharapkan, kepuasan, dan kebutuhan yang dirasakan oleh pengguna [5]. menurut Galin (2004) beberapa karakteristik yang digunakan untuk menilai kualitas sistem informasi yaitu accuracy, timeliness, relevance, informativeness, dan competitiveness seperti yang ditunjukkan pada Gambar 1.

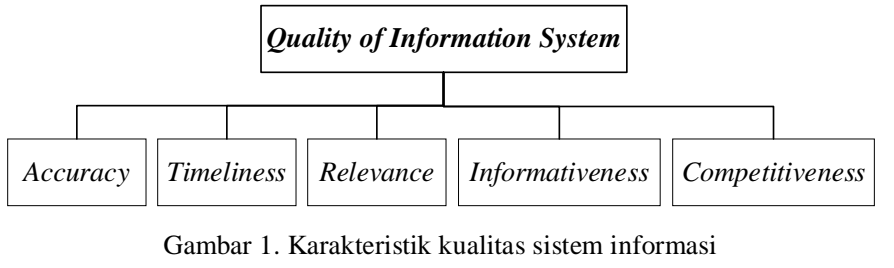

Gambar 1 merupakan karakteristik kualitas sistem informasi yang terdiri dari lima karakteristik untuk menilai kualitas dari sistem informasi, yaitu accuracy merupakan karakteristik untuk mengukur keakuratan informasi yang dihasilkan; Timeliness merupakan karakteristik untuk mengukur ketepatan waktu dari informasi yang dihasilkan; Relevance merupakan karakteristik untuk mengukur relevansi terhadap informasi yang dihasilkan; Informativeness merupakan karakteristik untuk mengukur kepuasan pengguna dari informasi yang dihasilkan, dan Competitiveness merupakan karakteristik untuk mengukur kemampuan dalam meningkatkan bisnis dari informasi yang dihasilkan [5].

\section{B. ISO/IEC 25010}

ISO/IEC 25010 merupakan pedoman yang digunakan untuk melakukan evaluasi perangkat lunak yang dikeluarkan oleh Canadian Standards Association pada tahun 2011. ISO/IEC 25010 adalah model baru dari seri ISO/IEC 250n yang merupakan pengembangan dari versi ISO/IEC 9126 [3]. Model ISO/IEC 25010 memiliki karakteristik kualitas yang dapat dipertimbangkan ketika melakukan evaluasi perangkat lunak. Pada ISO/IEC 25010 terdapat 2 model yang dapat digunakan untuk mengukur kualitas sistem, yaitu quality in use model, dan software product quality model.

\section{Quality in Use Model}

Quality in use model adalah model untuk menilai sejauh mana perangkat lunak dapat digunakan oleh pengguna tertentu dalam memenuhi kebutuhan bisnis yang spesifik dalam konteks penggunaan tertentu [3]. Quality in use model terdiri dari 5 karakteristik kualitas yang ditunjukan pada Gambar 2.

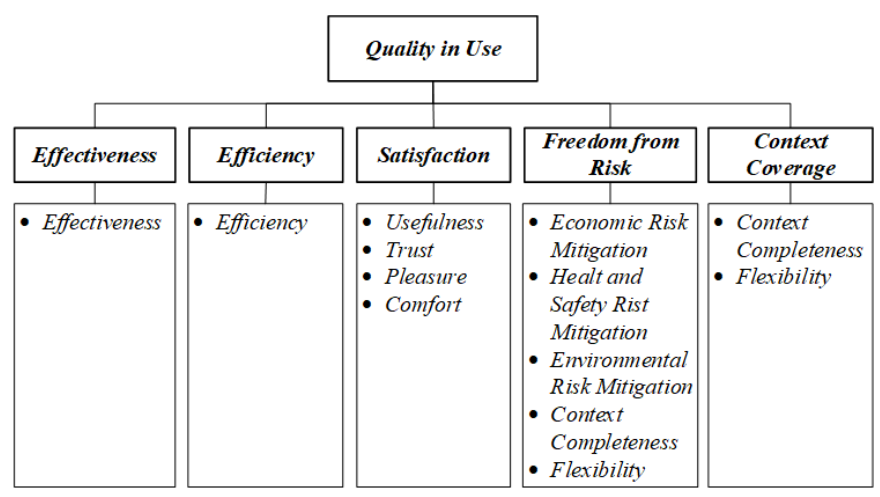

Gambar 2. Karakteristik Quality in Use Model

Gambar 2 merupakan karakteristik pada quality in use model yang terdiri dari: Effectiveness merupakan karakteristik untuk mengukur akurasi dan kelengkapan pengguna mencapai tujuan yang ditentukan; Efficiency merupakan karakteristik untuk mengukur sumber daya yang dikeluarkan terkait dengan akurasi dan kelengkapan yang digunakan pengguna untuk mencapai tujuan; Satisfaction adalah karakteristik untuk mengukur sejauh mana kebutuhan pengguna terpenuhi ketika 
suatu produk atau sistem digunakan dalam konteks penggunaan yang ditentukan; Freedom from Risk adalah karakteristik untuk mengukur sejauh mana suatu sistem memitigasi risiko potensial terhadap status ekonomi, kehidupan manusia, kesehatan, atau lingkungan; Context Completeness adalah karakteristik untuk mengukur sejauh mana suatu sistem digunakan dengan efektivitas, efisiensi, kebebasan dari risiko dan kepuasan dalam semua konteks penggunaan yang ditentukan [3].

\section{Software Product Quality Model}

Software product quality model adalah model yang hanya dapat diterapkan pada produk perangkat lunak, karena sebagian besar sub karakteristik terkait dengan perangkat lunak dan sistem [3]. Software product quality model terdiri dari 8 karakteristik kualitas yang ditunjukan pada Gambar 3.

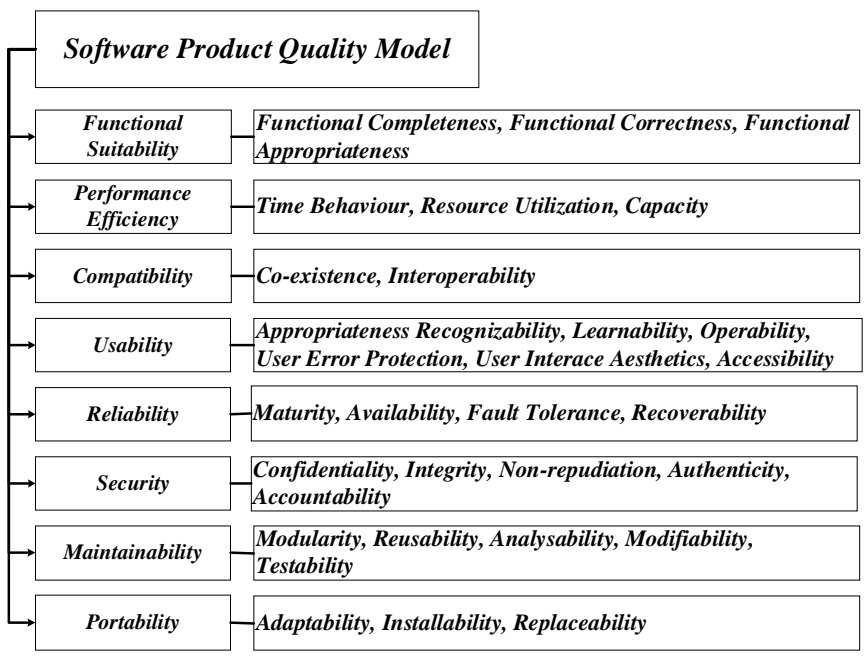

Gambar 3. Karakteristik Software Product Quality Model

Gambar 3 merupakan karakteristik dan sub karakteristik pada Software product quality model yang terdiri dari: Functional Suitability merupakan karakteristik untuk mengukur sejauh mana produk atau sistem menyediakan fungsi yang memenuhi kebutuhan ketika digunakan dalam kondisi tertentu; Performance Efficiency adalah karakteristik untuk mengukur kinerja relatif terhadap sumber daya yang digunakan dalam kondisi tertentu pada suatu sistem; Compatibility adalah karakteristik untuk mengukur sejauh mana suatu sistem dapat bertukar informasi dengan sistem lain dan melakukan fungsi yang disyaratkan saat berbagi lingkungan perangkat keras atau perangkat lunak yang sama; Usability adalah karakteristik untuk mengukur sejauh mana sistem dapat digunakan oleh pengguna untuk mencapai tujuan yang ditentukan dengan efektivitas, efisiensi, dan kepuasan dalam konteks penggunaan tertentu; Realiability adalah karakteristik untuk mengukur sejauh mana sistem dapat melakukan fungsi dalam kondisi yang ditentukan untuk periode waktu terentu; Security adalah karakteristik untuk mengukur suatu sistem dalam melakukan proteksi terhadap informasi dan data, sehingga sistem memiliki tingkat akses data sesuai dengan jenis dan tingkat otorisasi; Maintainability adalah karakteristik untuk mewakili tingkat efektivitas dan

Made Dwi Mulyawan: Pengukuran Kualitas Sistem Informasi... efisiensi dalam proses modifikasi untuk perbaikan sistem sesuai dengan penyesuaian dan perubahan pada lingkungan operasional; Portability adalah karakteristik untuk mewakili tingkat efektivitas dan efisiensi sistem dalam melakukan transfer dari satu perangkat ke perangkat lainnya.

\section{BAHAN DAN Metode}

Penelitian ini melakukan tinjauan terhadap penerapan ISO/IEC 25010 dalam menilai kualitas sebuah perangkat lunak, khususnya penelitian yang dilakukan oleh peneliti atau perusahaan di Indonesia. Data yang digunakan berasal dari dokumen resmi pemerintah, artikel jurnal, publikasi conference, dan dokumen lainnya. Data ini diperoleh melalui pengindeks atau mesin pencari seperti Google Scholar, ResearchGate, Neliti, dan IEEE Xplore. Skematik penelitian yang dilakukan ditunjukkan pada Gambar 4.

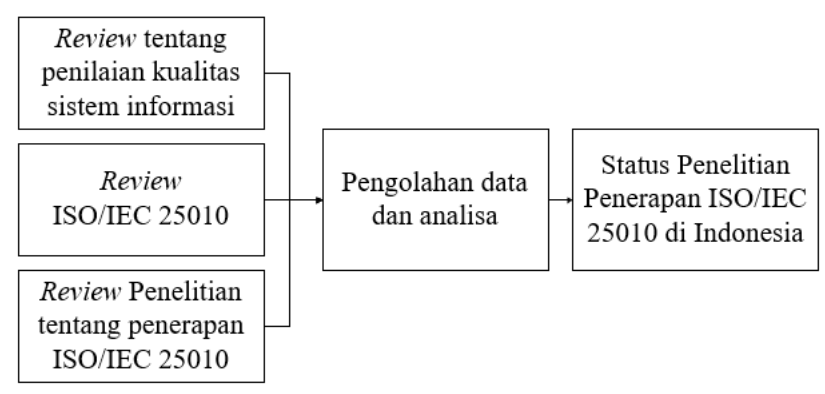

Gambar 4. Skematik penelitian

Penelitian dilakukan melalui beberapa tahapan. Tahapan pertama melakukan telaah literature tentang penelitian kualitas sistem informasi menggunakan model ISO/IEC 25010, review dari model kualitas ISO/IEC 25010, dan review tentang penilaian kualitas sistem informasi. Selanjutnya pada tahapan kedua dilakukan pengolahan data dan analisa dari hasil telaah literature untuk dilakukan mapping untuk mengetahui sejauh mana hasil proses pengukuran yang dilakukan berdasarkan karakteristik pada model ISO/IEC 25010. Pada tahapan ketiga dilakukan analisa terhadap status penelitian penerapan ISO/IEC 25010 di Indonesia.

\section{Hasil dan Pembahasan}

Berdasarkan dari telaah yang telah dilakukan, terdapat 30 buah dokumen yang membahas tentang penerapan ISO/IEC 25010 ini. Telaah detil dari setiap paper akan dijelaskan di bawah ini.

\section{A. Penerapan ISO/IEC 25010}

Penelitian mengenai penerapan model kualitas untuk menganalisis setiap aspek yang berkaitan dengan game online telah dilakukan oleh Wibawa (2019). Dalam penelitian ini dilakukan proses evaluasi dan perbandingan kualitas game online untuk mengetahui karakteristik, kekuatan dan kelemahan dari masing-masing game online, diantaranya: Atlantica Online, DoTA 2 dan Point Blank. Pengukuran kualitas dilakukan dengan menggunakan karakteristik model quality in use dari ISO/IEC 25010, yaitu: effectiveness, efficiency, satisfaction, freedom from risk, dan context p-ISSN:1693 - 2951; e-ISSN: 2503-2372 
coverage. Pengumpulan data dilakukan melalui pengisian kuesioner dan pengujian kinerja perangkat yang digunakan. Hasil dari penelitian yang dilakukan menunjukan bahwa Atlantica Online memiliki nilai kualitas yang lebih unggul dibandingkan dengan DoTA 2 dan Point Blank [7].

Pengukuran kualitas dilakukan oleh Andika dan Yanti (2018) pada aplikasi Augmented Reality Museum Bali menggunakan standar ISO/IEC 25010. Pengukuran dilakukan menggunakan karakteristik functional suitability, usability, performance efficiency dan compatibility. Analisis dilakukan berdasarkan use questionnaire yang diukur menggunakan skala likert. Hasil dari penelitian ini menunjukan bahwa aplikasi AR Museum Bali telah memenuhi aspek functional suitability, usability dan compatibility dengan kategori baik, serta aspek performance efficiency mendapatkan response time dengan rata-rata $3.59 \mathrm{~ms}$ [8].

Pengembangan Sistem Informasi Tracer Study yang dilakukan pada Universitas Islam Negeri (UIN) telah dilakukan oleh Anggraini (2019). Penelitian dilakukan untuk melakukan pengembangan sistem informasi yang berfungsi untuk mendapatkan sumber data untuk lulusan UIN. Rapid Application Development (RAD) digunakan sebagai metode pengembangan sistem yang terdiri dari planning, workshop design, dan implementasi. Model kualitas ISO/IEC 25010 digunakan untuk melakukan pengujian kinerja sistem informasi yang telah dikembangkan. Hasil pengujian dengan menggunakan karakteristik ISO/IEC 25010 menunjukan bahwa functional suitability dengan nilai 1 , performance efficiency dengan respons halaman kurang dari 5 detik, compatibility dapat dijalankan di beberapa browser dengan versi yang berbeda, reliability dengan nilai 100\%, usability dengan nilai $67,5 \%$, maintainability dengan nilai kurang dari $0,56 \%$, dan portability menunjukan bahwa situs web responsif dalam berbagai ukuran browser [9].

Penerapan framework berdasarkan ISO/IEC 25010 pada Sistem Informasi Akademik Institut Teknologi Sepuluh Nopember (SI Akademik ITS) telah dilakukan oleh Saptarini dkk (2016) untuk mengukur kualitas keamanan pada sistem informasi tersebut. Pengukuran kualitas keamanan dilakukan dengan menggunakan sub karakteristik pada aspek security, yaitu: confidentiality, integrity, accountability, authenticity, dan security compliance. Melalui penggunaan model kualitas ISO/IEC 25010 menunjukan bahwa terdapat peningkatan nilai keamanan sebesar 15,6\% sesuai dengan rekomendasi yang dihasilkan pada pengukuran kualitas sebelumnya. selain itu penggunaan model kualitas ini dapat mengungkapkan kelemahan pada SIA yang nantinya dapat dipergunakan sebagai rekomendasi dalam melakukan pembaruan sistem [10].

Evaluasi berbasis konteks terhadap aplikasi Intensive Care Unit dengan menggunakan quality in use ISO/IEC 25010 telah dilakukan oleh Ben dkk (2016). Proses evaluasi dilakukan berdasarkan aspek quality in use yang terdiri dari effectiveness, efficiency, satisfaction, freedom from risk, dan contect coverage. Proses pengumpulan data untuk proses evaluasi digunakan Evaluation Support System (ESS) yang memungkinkan untuk mengumpulkan data interaksi dan data kontekstual selama penggunaan aplikasi berbasis mobile. Berdasarkan hasil dari proses evaluasi menunjukan bahwa adanya ketergantungan pengukuran kriteria quality in use dengan perubahan atribut kontekstual yang meliputi lingkungan, platform dan pengguna [11].

Pengukuran kesesuaian fungsional pada Sistem Informasi Akademik (SIA) dengan pendekatan berorientasi tujuan telah dilakukan Puspaningrum dkk (2017). Pengukuran dilakukan menggunakan model ISO/IEC 25010 yang memfokuskan pada aspek functional suitability. Metode Goal Question Metrics (GQM) digunakan untuk mengidentifikasi tujuan bisnis untuk mengetahui strategi perencanaan institusi. Hasil dari penelitian yang dilakukan menunjukan bahwa pengukuran menggunakan pendekatan berorientasi tujuan menjadi lebih objektif dan cocok untuk kebutuhan peningkatan kualitas Sistem Informasi Akademik yang digunakan pada institusi daripada pengukuran dengan ISO/IEC 25010 saja [12].

Penelitian dalam mengevaluasi Cardiac Decision Support System (Cardiac DSS) telah dilakukan oleh Kadi dkk (2016) dengan menggunakan model kualitas ISO/IEC 25010. Dalam proses pengukuran kualitas sistem, penelitian ini memfokuskan pada aspek functional suitability, realiability, performance efficiency, dan penggunaan eksternal karakteristik operability yang diidentifikasi sebagai aspek yang paling berpengaruh pada persyaratan Cardiac DSS. Hasil penelitian yang telah dilakukan menunjukkan bahwa karakteristik yang digunakan dalam evaluasi lebih berpengaruh pada persyaratan Cardiac DSS dibandingkan dengan karakteristik lainnya. Rekomendasi untk penelitian selanjutnya, dapat dilakukan evaluasi empiris dari Cardiac DSS yang didasarkan pada hasil penelitian yang telah dilakukan [13].

Evaluasi perangkat lunak telah dilakukan oleh Julieta dkk (2018). Penelitian yang telah dilakukan ini mengukur kualitas pada tiga aplikasi katalog produk berbasis web dari aspek security dengan menggunakan standar ISO/IEC 25010 menggunakan metode Goal Question Metric (GQM). Penelitian ini melakukan perbandingan kualitas terhadap 3 aplikasi web. Hasil dari penelitian menunjukkan bahwa dari tiga aplikasi web yang dievaluasi, hanya dua yang berhasil lulus standar kualitas. Hasil pengukuran kualitas keamanan pada aplikasi web yang tidak lulus standar kualitas berada pada persentase dibawah 50\% [14].

Penelitian yang dilakukan oleh Iqbal dan Babar (2016) dengan melakukan pendekatan dalam menganalisis persyaratan kualitas decision support system. Penelitian yang dilakukan membahas mengenai kebutuhan pengukuran kualitas pada decision support system pada Internet Banking dengan menggunakan ISO/IEC 25010, Fuzzy Logic dan Likert Scale. Hasil dari penelitian ini menunjukan bahwa aspek keamanan sistem pada Internet Banking menjadi aspek yang paling penting untuk ditingkatkan dalam melakukan pengembangan maupun perbaikan sistem tersebut [15].

Pengukuran kualitas untuk sistem informasi geografis (WebGIS) menggunakan pengembangan berorientasi objek telah dilakukan oleh Falih dkk (2017). Penelitian dilakukan dengan menggunakan model kualitas ISO/IEC 25010 dan GQM untuk mengkarakteristik metrik yang digunakan. Tujuan penelitian yaitu untuk mengusulkan referensi pengembangan berorientasi objek untuk meningkatkan kualitas WebGIS. Analisis korelasi Pearson digunakan untuk melihat hubungan antara metrik internal dengan metrik eksternal yang menunjukkan hasil adanya konektivitas yang 
kuat antara metrik tersebut. Hasil dari penelitian ini menunjukkan bahwa model kualitas ISO/IEC telah berhasil diterapkan pada sistem informasi geografis berbasis web [16].

Penerapan model kualitas ISO/IEC 25010 telah dilakukan oleh Fath dkk (2018) untuk menyusun kerangka kerja pada portal e-government dalam proses pengukuran kualitas portal tersebut. Proses yang dilakukan dalam menyusun kerangka kerja yaitu melakukan mapping terhadap karakteristik dan sub karakteristik model ISO/IEC 25010 terhadap back-end, web design, web content, dan service. Tujuan dari penelitian ini yaitu menentukan karakteristik dan sub karakteristik yang terbaik dalam melakukan proses pengukuran pada 5 aspek yang terdapat pada portal e-government [17].

Penelitian mengenai penerapan ISO/IEC 25010 dalam proses evaluasi kualitas diagnostik aksesibilitas Digital System telah dilakukan oleh Calvo dkk (2019). Penelitian ini menggunakan aspek functional suitability dan tool WCAG 2.0 serta AA Level dalam melakukan pengukuran kualitas terhadap aksesibilitas web. Penggunaan tool pada proses pengukuran ini bertujuan untuk mempermudah dalam menentukan kebutuhan fungsional, serta penggunaan skor dalam mengukur karakteristik yang dievaluasi dapat mempermudah peneliti dalam memberikan rekomendasi berdasarkan bobot dan kriteria yang dipilih [18].

Penelitian mengenai penggunaan standar kualitas ISO/IEC 25010 untuk mengukur kualitas pada aplikasi Bussiness Activity Monitoring (BAM) telah dilakukan oleh Martino dkk (2020). Pengukuran aplikasi dilakukan dengan menggunakan karakteristik functional suitability untuk mengukur fungsional pada aplikasi BAM. Dari hasil testing dengan menggunakan User Acceptance Test (UAT), aplikasi BAM yang digunakan masih memiliki beberapa ketidaksesuaian dengan hasil yang diharapkan. Sehingga aplikasi BAM ini dapat memenuhi karakteristik functional suitability dalam ketiga sub karakteristik jika ketidaksesuaian yang telah ditemukan dapat segera diperbaiki [19].

Penelitian yang dilakukan oleh Lesmideyarti dkk (2017) dalam mengukur kualitas dan mengevaluasi Sistem Informasi Akademik Universitas Borneo Tarakan (SI Akademik UBT) dengan melakukan penyusunan dan pengujian metrik operabilitas menggunakan model ISO/IEC 25010. Selain itu pengukuran dilakukan dengan metode USE Questionnaire dan AHP dalam proses analisis data yang diperlukan. Hasil penelitian menunjukkan bahwa model kualitas ISO/IEC 25010 lebih akurat dibandingkan dengan model lama, karena adanya penambahan sub karakteristik helpfullness dan technical accessibility dalam proses meningkatkan akurasi sehingga SI Akademik UBT telah memenuhi standar pengukuran kualitas dengan nilai $70 \%$ [20].

Pengukuran kualitas sistem informasi kegiatan sekolah berbasis mobile website telah dilakukan oleh Ghaffur dan Nurkhamid (2017) berdasarkan model kualitas ISO/IEC 25010. Penelitian dilakukan dengan tujuan untuk menjamin tingkat kualitas pada sistem informasi yang digunakan pada SMK Negeri 2 Yogyakarta. Instrumen yang digunakan yaitu: black-box testing, USE Questionnaire, Yslow tools dan Pingdom Website Speed Test. Hasil pengukuran menunjukkan mobile website telah memenuhi standar ISO/IEC 25010 pada karakteristik functional suitability dan compatibility sebesar $100 \%$, usability sebesar $82 \%$ dan performance efficiency dengan nilai 94.2 dan rata-rata kecepatan akses sebesar 0.9305 detik [21].

Klasifikasi kualitas perangkat lunak berdasarkan ISO/IEC 25010 menggunakan AHP dan Fuzzy Mamdani telah dilakukan oleh Wattiheluw dkk (2019). Karakteristik functional suitability, performance efficiency, usability dam reliability digunakan untuk mengklasifikasikan kualitas situs e-commerce. Metode AHP digunakan untuk menilai bobot kepentingan antar karakteristik, sedangkan Fuzzy Mamdani digunakan untuk memberikan label kualitas berdasarkan bobot karakteristik yang dihasilkan. Hasil klasifikasi yang dilakukan menghasilkan nilai akurasi sebesar 0,684 yang digunakan sebagai bahan pengembang untuk meningkatkan kualitas situs web e-commerce [22].

Penelitian yang dilakukan oleh Tangkudung dkk (2019) yaitu evaluasi terhadap website Universitas Negeri Gorontalo dengan menggunakan ISO/IEC 25010. Fokus dalam penelitian yang dilakukan yaitu melakukan evaluasi pada aspek functional suitability, performance efficiency, portability, dan usability. Adapun hasil dari evaluasi yang dilakukan terhadap website tersebut adalah aspek functional suitability memenuhi syarat dengan kategori baik. Performance efficiency dengan skor rata-rata 45,18, dengan page speed dan Yslow dengan skor rata-rata 62,53, dan waktu respon 17,64 detik. Usability memiliki nilai SUS sebesar 57,38, dan aspek portability berjalan dengan baik (tanpa error). Website perlu dilakukan perbaikan pada aspek performance efficiency dan usability untuk mencapai sistem yang berkualitas menurut ISO/IEC 25010 [23].

Penelitian yang dilakukan oleh Afiah dkk (2019) yaitu evaluasi kualitas penggunaan pada website Bandung Smart City berdasarkan ISO/IEC 25010. Penelitian ini menggunakan model quality in use untuk mengukur efektifitas, efisiensi, tingkat kepuasan website dalam memenuhi kebutuhan pengguna. Hasil dari penelitian yang dilakukan adalah sebuah prototype yang dapat menghasilkan peningkatan skor efektifitas, efisiensi dan tingkat kepuasan dari website Bandung Smart City dengan rata-rata sebesar $77,17 \%$. Penerapan standar ISO/IEC 25010 dalam penelitian ini meningkatkan nilai rata-rata kualitas website sebesar $15,9 \%$ [24].

Evaluasi kualitas terhadap aplikasi KMS Balita dan Bunda berbasis Android telah dilakukan oleh Harun (2020). Evaluasi dilakukan dengan metode PIECES dan ISO/IEC 25010. Metode PIECES digunakan untuk analisis aspek yang menjadi fokus pada pengukuran yang akan diukur berdasarkan aspek pada model kualitas ISO/IEC 25010. Penelitian ini menggunakan USE Questionnaire dalam mengumpulkan data yang diperlukan dalam proses evaluasi yang dihitung dengan menggunakan skala likert. Adapun hasil dari proses evaluasi kualitas aplikasi KMS Balita dan Bunda adalah, aspek functional suitability sebesar 71,6\%, aspek performance efficiency sebesar 73,8\%, aspek compatibility sebesar $75 \%$, usability sebesar $74 \%$, reliability sebesar $72,8 \%$, security 
69,3\%, maintainability dan portability masing-masing sebesar $75,1 \%$ dan $73,8 \%$ [25].

Pengukuran kualitas pada aplikasi layanan transportasi GOJEK menggunakan ISO/IEC 25010 telah dilakukan oleh Izzatillah (2019). Tujuan dari penelitian yang dilakukan yaitu untuk menghasilkan kinerja aplikasi yang baik dengan menerapkan model kualitas ISO/IEC 25010. Penelitian ini menggunakan karakteristik pada quality in use model dan product quality model. Pada product quality model, pengukuran difokuskan pada aspek functional suitability, performance efficiency, compatibility, usability, reliability, dan security. Hasil dari proses pengukuran yaitu, dimensi product quality pada perangkat Android sebesar 79,30\% dan pada perangkat iOS sebesar 91,37\%. Sedangkan untuk dimensi quality in use adalah 76,22\% dari kualitas maksimun nilai penggunaan aplikasi selular yang sebesar 94,75\%. Hal ini menunjukkan bahwa aplikasi GOJEK memiliki kualitas yang baik dalam kualitas produk dan kualitas pada dimensi penggunaan atau perspektif pengguna [26].

Pengukuran kualitas Sistem Ujian Harian dengan menggunakan ISO/IEC 25010 telah dilakukan oleh Larasati dkk (2017). Penelitian dilakukan melalui pengukuran kualitas dengan karakteristik software product quality model. Adapun hasil dari pengukuran kualitas Sistem Ujian Harian yaitu pada aspek functional suitability memperoleh persentase sebesar $100 \%$, performance efficiency, dan compatibility memperoleh hasil dengan persentase sebesar 100\%. Aspek usability mendapatkan persentase sebesar $87,7 \%$, reliability dengan tingkat maturity sistem sebesar $100 \%$, dan pada aspek security mendapatkan tingkat keamanan $100 \%$ atau berada pada level safe [27].

Evaluasi kualitas pada aplikasi mobile E-Learning telah dilakukan oleh Razi dan Amali (2014) menggunakan model kualitas ISO/IEC 25010. Proses pengumpulan data dilakukan melalui kuesioner yang diukur dengan skala likert. Pengukuran aplikasi dilakukan dengan memfokuskan pada 6 karakteristik software product quality model yang dihubungkan dengan dimensi aplikasi dalam konteks cara pembelajaran. Adapun hasil pengukuran terhadap masingmasing aspek, yaitu: functional suitability sebesar $90 \%$, reliability dengan nilai $93,75 \%$, portability dengan nilai $87,5 \%$, maintainability dengan nilai $87,5 \%$, performance efficiency dengan nilai sebesar $98,75 \%$ dan usability dengan nilai $100 \%$ [28].

Evaluasi pada e-government dengan menggunakan ISO/IEC 25010 juga telah dilakukan oleh Rahayuda (2017). Evaluasi dilakukan dengan menilai aspek fungsionalitas, kehandalan, penggunaan, efisiensi, pemeliharaan, dan portabilitas dari e-government. Hasil dari evaluasi functional suitability dengan nilai $90 \%$, tingkat security berada pada $81.25 \%$, reliability dengan tingkat kematangan sistem berada pada persentase $82,14 \%$, performance efficiency dengan nilai $80 \%$, usability sebesar $88,98 \%$, portability dengan nilai $100 \%$, dan maintainability dari sistem $77,78 \%$ dapat diperbaiki secara langsung, sedangkan $28,58 \%$ memerlukan penghentian sementara [29].

Penelitian yang dilakukan oleh Widiantika dkk (2019) melakukan pengukuran kualitas pada aplikasi God Temple dengan menggunakan ISO/IEC 25010. Pengukuran dilakukan dengan menilai aspek fungsional, kegunaan, kinerja, dan kompatibilitas dari aplikasi mobile tersebut. Hasil dari pengukuran menunjukkan aplikasi God Temple telah memenuhi pada aspek functional suitability sebesar 100\%, compatibility sebesar $100 \%$ yang menunjukkan bahwa aplikasi ini sudah kompatibel pada beberapa sistem operasi Android, performance efficiency dengan nilai 100\%, dan usability dengan tingkat kegunaan sebesar 90,32\% [30].

Pengukuran kualitas dari aplikasi Fidusia telah dilakukan oleh Aen dan Finandhita (2017) dengan menggunakan model kualitas ISO/IEC 25010. Fidusia merupakan aplikasi berbasis $w e b$ yang digunakan untuk pembuatan akta notaris. Penilaian kualitas dilakukan terhadap 7 karakteristik pada software product quality model. Adapun hasil dari pengukuran menunjukkan bahwa aplikasi Fidusia memiliki reliability dengan tingkat maturity yang rendah, yaitu sebesar 32,2\%. Sedangkan untuk functional suitability sebesar $61 \%$, performance efficiency dengan persentase $66,8 \%$, tingkat usability sebesar 59,6\%, portability sebesar 55,4\%, dan maintainability sebesar $62 \%$, dimana 5 aspek yang dinilai pada aplikasi ini telah memenuhi persyaratan ISO/IEC 25010 dengan level medium. Sedangkan untuk tingkat security, aplikasi ini telah memenuhi level high dengan persentase sebesar $67,2 \%$ [31].

Pengujian aplikasi Tourism Augmented Reality (Tourism AR) telah dilakukan oleh Ranawijaya dkk (2020). Aplikasi AR digunakan sebagai salah satu media promosi pariwisata di Kabupaten Banyumas. Tahapan pengujian dilakukan menggunakan model kualitas ISO/IEC 25010 yang berfokus pada aspek fungsional, kegunaan dan kompatibilitas aplikasi. Adapun hasil dari pengujian menunjukkan bahwa aplikasi Tourism AR memiliki nilai functional suitability sebesar $97,5 \%$, nilai usability sebesar 88,6\%, dan aplikasi ini telah kompatibel pada beberapa perangkat mobile Android dengan tingkat compatibility sebesar 100\% [32].

Analisis kualitas telah dilakukan oleh Setiawan (2017) pada sistem informasi pantauan pembentukan karakter siswa. Tujuan dari penelitian yang dilakukan adalah untuk menjamin tingkat kualitas fungsionalitas sistem menggunakan ISO/IEC 25010. Pengukuran kualitas dilakukan berdasarkan lima karakteristik pada software product quality model. Adapun hasil dari pengukuran yang dilakukan yaitu aspek functional suitability berada pada kategori good dengan persentase sebesar $100 \%$, usability pada tingkat $85,3 \%$, reliability sebesar $100 \%$, performance efficiency pada kategori approve dengan nilai sebesar $95 \%$, dan maintainability berada pada level high dengan persentase sebesar $100 \%$ [33].

Penelitian dilakukan oleh Rochimah dkk (2017) dengan melakukan implementasi pola desain dan pengukuran kualitas pada Sistem Informasi Akademik (SIAKAD) menggunakan ISO/IEC 25010. Pengukuran dilakukan dengan memfokuskan pada aspek usability dan maintainability. Tujuan dari penelitian yang dilakukan yaitu untuk mengetahui pengaruh pola desain terhadap kualitas perangkat lunak. Hasil menunjukkan bahwa pola desain mempengaruhi kualitas modul dalam tingkat yang signifikan. Adapun hasil dari pengukuran yang telah dilakukan yaitu maintainability berada pada tingkat $97 \%$, sedangkan usability pada tingkat $98,5 \%$ [34].

Pengukuran kualitas terhadap aplikasi text summarization dilakukan oleh Maryana dan Kurniawati (2018) menggunakan 
DOI: https://doi.org/10.24843/MITE.2021.v20i01.P02

model ISO/IEC 25010. Pengukuran dilakukan dengan menggunakan karakteristik pada quality in use model dan software product quality model. Adapun hasil dari proses pengukuran kualitas kegunaan perangkat lunak dengan aspek pada quality in use model adalah sebesar 79,92\%, sedangkan untuk kualitas perangkat lunak pengukuran difokuskan pada 6 aspek pada software product quality model. Hasil pengukuran menunjukkan functional suitability sistem berada pada persentase $83,7 \%$, performance efficiency sebesar $74,2 \%$, compatibility sebesar $68,4 \%$ dan usability pada tingkat $62,5 \%$. Sedangkan untuk reliability dan portability sistem memiliki kualitas yang sedang, pada dengan nilai 56,2\% dan 55\% [35].

Penerapan model kualitas ISO/IEC 25010 pada Sistem Rekomendasi Bursa Kerja Khusus (SI BKK) telah dilakukan oleh Maharani dkk (2018). Tujuan dari penelitian ini adalah untuk mengetahui apakah sistem yang telah dirancang telah memenuhi standar kualitas berdasarkan ISO/IEC 25010. Pengujian sistem dilakukan dengan menggunakan 6 aspek software product quality model, yaitu fungsional, kegunaan, pemeliharaan, portabilitas, reliabilitas, dan keamanan. Adapun hasil pengujian yang dilakukan menunjukkan functional suitability sistem berada pada persentase $97,5 \%$, tingkat usability dengan nilai $85,7 \%$, reliability dengan nilai $100 \%$, security dengan nilai sebesar $80 \%$, maintainability dengan nilai $80 \%$, dan portability dengan persentase $90 \%$ [36].

\section{B. Penggunaan Quality in Use Model}

Quality in use model digunakan sebagai penilaian kualitas suatu sistem yang diukur dari aspek penggunaan sistem. Sebaran penelitian yang menggunakan karakteristik quality in use model dapat dilihat pada Tabel 1.

TABEL I

PENGGUNAAN QUALITY IN USE MODEL

\begin{tabular}{|l|l|}
\hline \multicolumn{1}{|c|}{ Quality in Use Model } & \multicolumn{1}{c|}{ Penelitian } \\
\hline Effectiveness & {$[7],[11],[24],[26],[35]$} \\
\hline Efficiency & {$[7],[11],[24],[26],[35]$} \\
\hline Satisfaction & {$[7],[11],[24],[26],[35]$} \\
\hline Freedom from Risk & {$[7],[11],[24],[26],[35]$} \\
\hline Context Coverage & {$[7],[11],[24],[26],[35]$} \\
\hline
\end{tabular}

Berdasarkan hasil mapping dari penggunaan karakteristik quality in use model pada setiap penelitian, menunjukkan bahwa seluruh karakteristik berperan penting dalam pengukuran kualitas penggunaan sistem. Pengukuran kualitas penggunaan sistem dilakukan pada jenis perangkat lunak yang berbeda. Penggunaan karakteristik quality in use model ditunjukkan pada Gambar 5.

\section{Penggunaan Quality in Use Model}

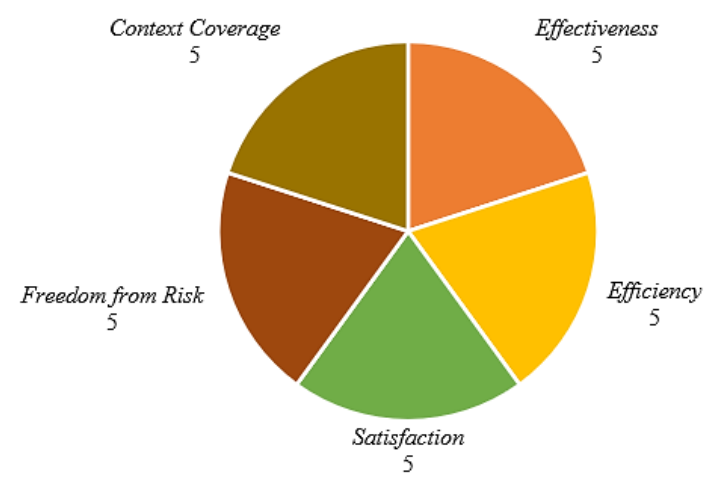

Gambar 5. Penggunaan karakteristik quality in use model

Gambar 5 merupakan jumlah penggunaan karakteristik quality in use model dalam pengukuran kualitas kegunaan dari perangkat lunak. Hasil pengukuran dari kualitas penggunaan sistem menunjukan persentase yang berbeda, seperti ditunjukkan pada Gambar 6.

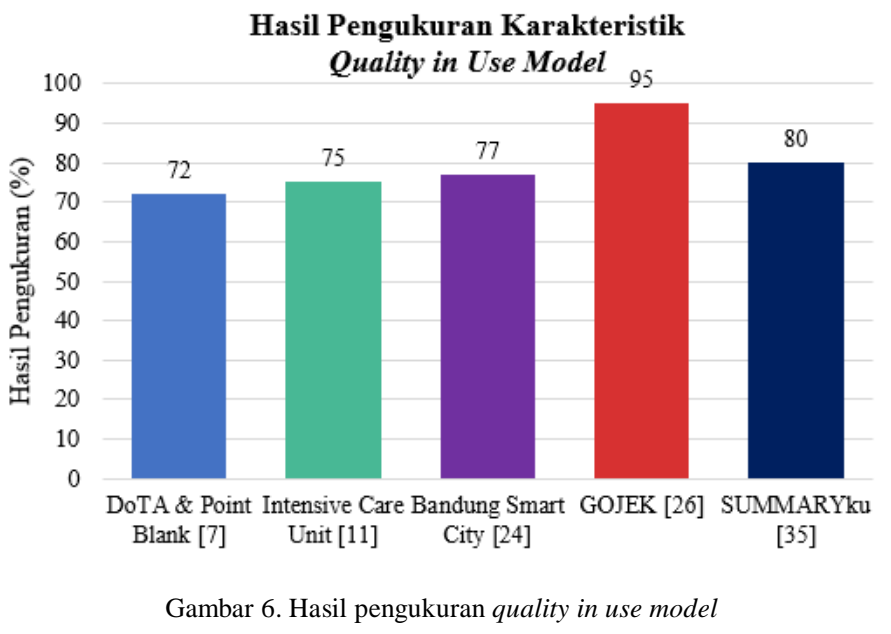

Gambar 6 merupakan hasil pengukuran quality in use model pada lima perangkat lunak. Pengukuran kualitas penggunaan pada aplikasi GOJEK menunjukkan persentase yang paling tinggi, yaitu sebesar 95\%. Sedangkan untuk Game Online DoTa dan Point Blank sebesar 72\%, aplikasi Intensive Care Unit sebesar 75\%, dan Bandung Smart City sebesar 77\%. Tingkat akurasi penggunaan quality in use model untuk mengukur kualitas penggunaan sistem sangat baik, dilihat pada penggunaan model kualitas dapat meningkatkan hasil kualitas penggunaan website Bandung Smart City sebesar $15,9 \%$.

Pengukuran kualitas penggunaan pada aplikasi GOJEK menunjukkan hasil yang paling tinggi dibandingkan dengan perangkat lunak lainnya, yaitu sebesar $95 \%$. Hal ini didukung karena GOJEK merupakan salah satu perusahaan startup yang menyandang status decacorn, dengan jumlah pengguna saat ini sebanyak 50 Juta lebih dan menjadi service platform terbesar di Asia Tenggara [41]. Sehingga berdasarkan dari pengukuran kualitas penggunaan yang telah dilakukan, 
aplikasi GOJEK telah memenuhi persyaratan kualitas penggunaan.

\section{Penggunaan Software Product Quality Model}

Penggunaan software product quality model difokuskan untuk menilai suatu perangkat lunak. Penilaian dapat dilakukan dengan mengukur aspek yang ada, seperti functional suitability, performance efficiency, compatibility, usability, reliability, security, maintainability, dan portability dari suatu perangkat lunak. Berdasarkan hasil telaah literature yang dilakukan, maka dapat dilakukan mapping terhadap penggunaan karakteristik dalam penelitian yang menerapkan model kualitas ISO/IEC 25010 untuk pengukuran kualitas perangkat lunak. Hasil mapping dari penggunaan karakteristik Software Product Quality Model dapat dilihat pada Tabel 2.

TABEL II

PENGGUNAAN SOFTWARE PRODUCT QUALITY MODEL

\begin{tabular}{|l|l|}
\hline $\begin{array}{c}\text { Karakteristik Software } \\
\text { Product Quality Model }\end{array}$ & \multicolumn{1}{|c|}{ Penelitian } \\
\hline \multirow{3}{*}{ Functional Suitability } & {$[8],[9],[12],[13],[15],[16],[18],[19],[20]$} \\
& {$[21],[22],[23],[25],[26],[27],[28],[29]$} \\
& {$[30],[31],[32],[33],[35],[36]$} \\
\hline \multirow{3}{*}{ Performance Efficiency } & {$[8],[9],[13],[15],[16],[17],[20],[21],[22]$} \\
& {$[23],[25],[26],[27],[28],[29],[30],[31]$} \\
& {$[33],[35]$} \\
\hline \multirow{2}{*}{ Compatibility } & {$[8],[9],[15],[16],[17],[20],[21],[25],[26]$} \\
& {$[27],[30],[32],[35]$} \\
\hline & {$[8],[9],[15],[16],[20],[21],[22],[23],[25]$} \\
Usability & {$[26],[27],[28],[29],[30],[31],[32],[33]$} \\
& {$[34],[35],[36]$} \\
\hline \multirow{2}{*}{ Reliability } & {$[9],[13],[15],[16],[17],[20],[22],[25]$} \\
& {$[26],[27],[28],[29],[31],[35],[36]$} \\
\hline \multirow{2}{*}{ Security } & {$[10],[14],[15],[16],[17],[20],[25],[26]$} \\
& {$[27],[29],[31],[36]$} \\
\hline \multirow{2}{*}{ Maintainability } & {$[9],[15],[16],[20],[25],[28],[29],[31]$} \\
& {$[33],[34],[36]$} \\
\hline \multirow{2}{*}{ Portability } & {$[9],[15],[16],[20],[25],[28],[29],[31]$} \\
& {$[35],[36]$} \\
\hline
\end{tabular}

Tabel 2 menunjukkan sebaran karakteristik yang digunakan untuk pengukuran kualitas perangkat lunak berdasarkan karakteristik software product quality model. Pemilihan karakteristik dalam melakukan pengukuran kualitas perangkat lunak dapat dilakukan dengan memfokuskan pada aspek utama dalam perangkat lunak, sehingga hasil dari pengukuran kualitas nantinya dapat sesuai dengan harapan. Jumlah penelitian yang menggunakan karakteristik software product quality model ditunjukkan pada Gambar 7.

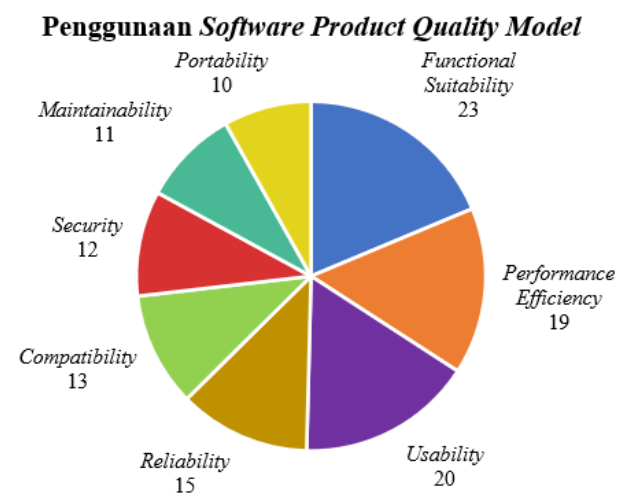

Gambar 7. Penggunaan karakteristik software product quality model

Gambar 7 merupakan jumlah penggunaan pada setiap karakteristsik karakteristik software product quality model. Aspek functional suitability, performance efficiency, usability, dan reliability menjadi karakteristik yang banyak digunakan dalam mengukur kualitas perangkat lunak. Menurut Wattiheluw dkk (2019) keempat karakteristik ini diperlukan untuk mengukur perangkat lunak yang baru selesai dikembangkan, sehingga pengukuran lebih fokus pada kesesuaian fungsional, kinerja sistem, kegunaan, dan tingkat kematangan dari perangkat lunak yang dikembangkan [22]. Selain itu beberapa penelitian juga memakai karakteristik compatibility, security, maintainability, dan portability dengan melihat kebutuhan atau kepentingan aspek yang dilakukan pengukuran. Pemilihan karakteristik dalam melakukan suatu pengukuran kualitas perangkat lunak, dapat dilakukan dengan melihat kebutuhan utama dari perangkat lunak yang akan dilakukan pengukuran. Sehingga dalam pengukuran nantinya peneliti dapat lebih fokus dalam penilaian aspek penting dari perangkat lunak yang akan dinilai kualitasnya. Gambar 8 merupakan hasil dari penggunaan karakteristik functional suitability.

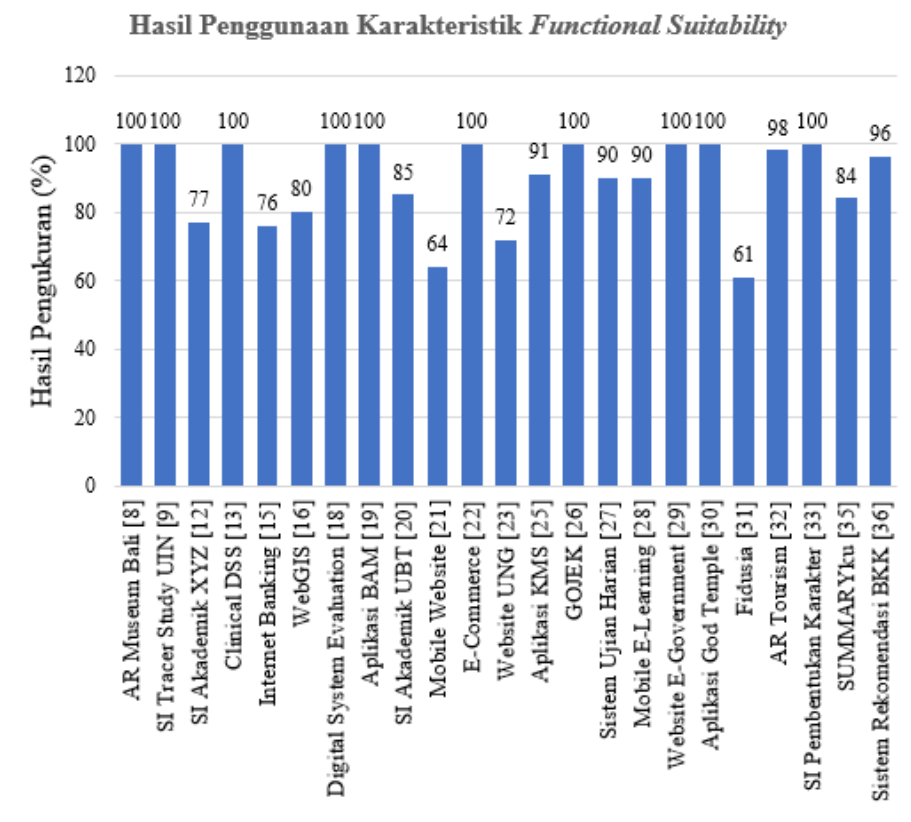

Gambar 8. Hasil penggunaan karakteristik functional suitability

Setiap penelitian yang menggunakan karakteristik functional suitability menunjukkan hasil yang berbeda-beda. Aplikasi Fidusia mendapatkan hasil yang paling rendah dengan persentase $61 \%$ disebabkan adanya beberapa fungsional yang mengalami error. Selain itu pengukuran yang memfokuskan dengan menggunakan satu karakteristik juga dapat meningkatkan hasil yang lebih baik, seperti yang dilakukan pada aplikasi BAM yang memfokuskan penilaian pada aspek fungsional saja. Hasil dari penelitian yang dilakukan dapat menemukan kesesuaian fungsional sistem dengan hasil yang diharapkan yaitu sebesar $100 \%$.

Penggunaan karakteristik performance efficiency dilakukan untuk mengetahui kualitas kinerja dari perangkat lunak. Adapun hasil setiap penelitian dapat dilihat pada Gambar 9. 


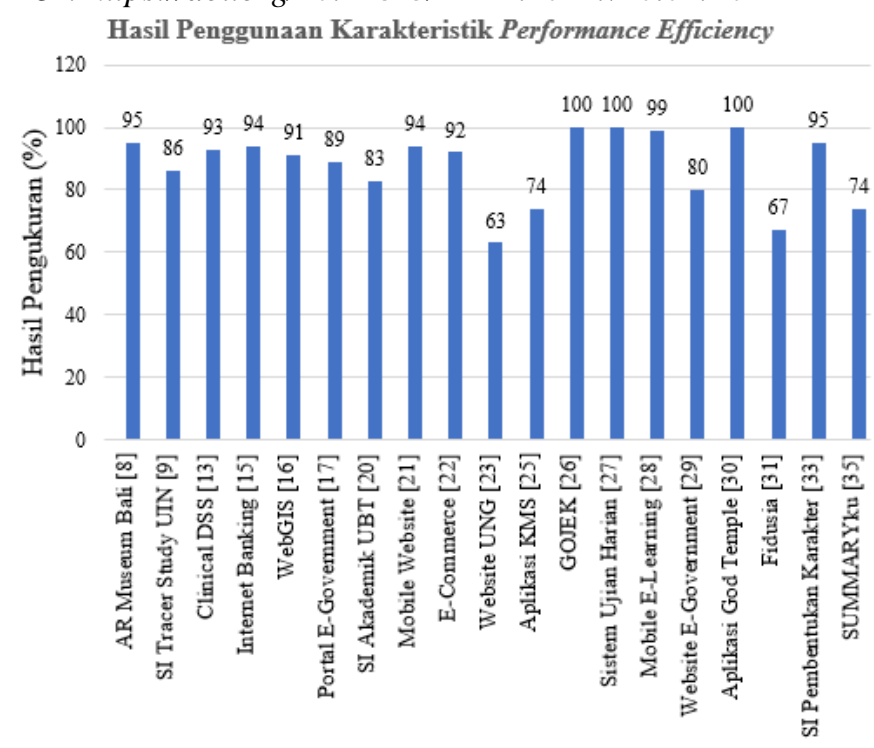

Gambar 9. Hasil penggunaan karakteristik performance efficiency

Penggunaan karakteristik performance efficiency pada setiap penelitian menunjukkan hasil yang berbeda-beda. website UNG mendapatkan hasil yang paling rendah dengan persentase $63 \%$, dimana hal ini disebabkan oleh respon yang terlalu lama yakni 17 detik dalam menampilkan halaman website, sehingga website tersebut tidak memenuhi persyaratan kualitas performance efficiency. Menurut Andika dan Yanti (2018) tingkat akurasi dalam melakukan pengukuran kualitas performance efficiency pada sistem berpengaruh pada processor dan RAM yang digunakan [8]. Sehingga untuk meningkatkan kualitas kinerja sistem, dapat dilakukan dengan penyesuaian perangkat yang digunakan dengan kebutuhan dari sistem.

Penggunaan karakteristik compatibility dilakukan untuk mengetahui kondisi kecocokan fungsional perangkat lunak dengan hardware dan sistem operasi yang digunakan. Adapun hasil setiap penelitian yang menggunakan karakteristik compatibility dapat dilihat pada Gambar 10.

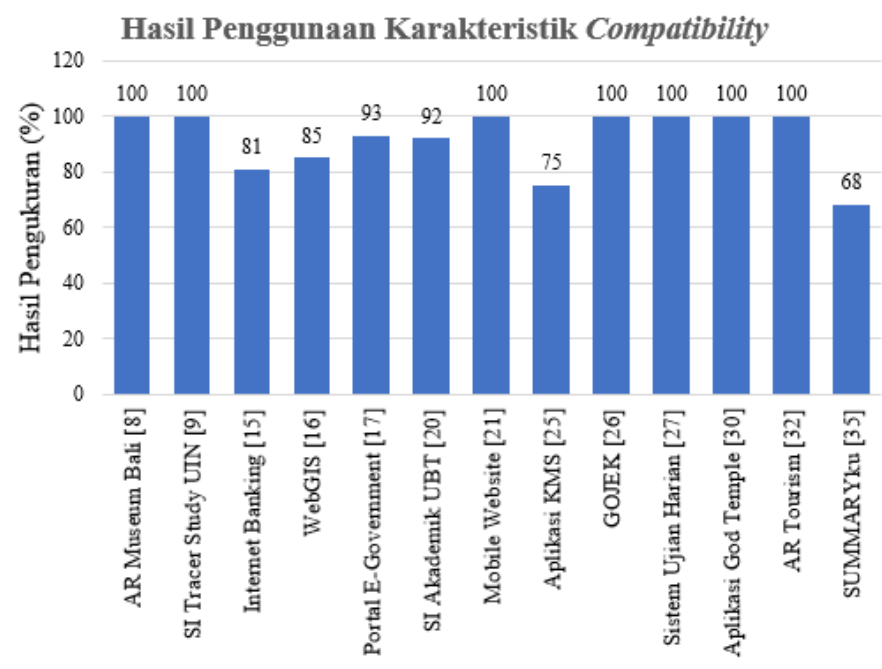

Gambar 10. Hasil penggunaan karakteristik compatibility
Penggunaan karakteristik compatibility setiap penelitian menunjukkan hasil dengan rata-rata yang sudah baik. Perbedaan dari hasil pengukuran disebabkan oleh penggunaan metode perhitungan dan cara pengujian yang berbeda. Pada aplikasi KMS Balita \& Bunda, aplikasi GOJEK, dan SUMMARYku dilakukan pengukuran dengan menggunakan skala likert, sehingga nilai dari kualitas compatibility disesuaikan dengan nilai pembobotan pada kuesioner yang diperoleh dari responden. Sedangkan pada aplikasi AR Museum Bali, SI Tracer Study UIN, Mobile Website, Sistem Ujian Harian, aplikasi God Temple, dan AR Tourism memperoleh persentase sebesar $100 \%$, melalui pengujian secara langsung pada device yang sesuai dengan kebutuhan perangkat lunak.

Penggunaan karakteristik usability dilakukan untuk mengetahui apakah perangkat lunak dapat digunakan oleh pengguna untuk mencapai tujuan tertentu dengan efektif. Adapun hasil pengukuran pada setiap penelitian yang dilihat pada Gambar 11.

\section{Hasil Penggunaan Karakteristik Usability}

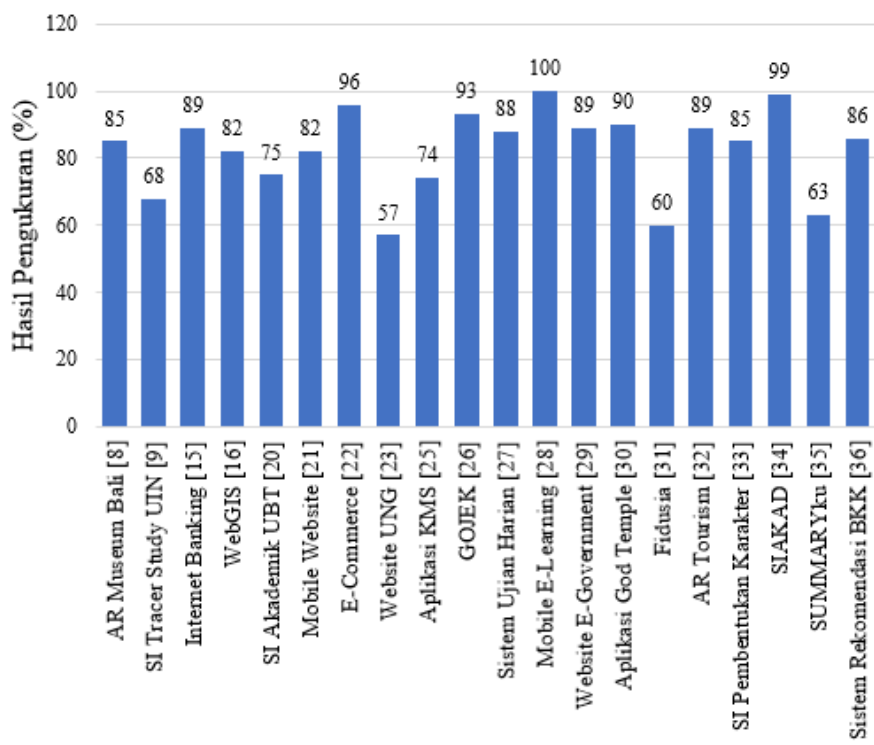

Gambar 11. Hasil penggunaan karakteristik usability

Penggunaan karakteristik usability pada setiap penelitian menunjukkan hasil yang berbeda-beda. Nilai kualitas terendah terdapat pada website Universitas Negeri Gorontalo, hal ini disebabkan oleh beberapa pengguna yang kesulitan dalam menggunakan sistem informasi, sehingga sistem tersebut memiliki kualitas yang rendah namun masih dalam kategori acceptability ranges. Sedangkan untuk hasil kualitas tertinggi diperoleh pada Mobile E-Learning, dimana nilai kegunaan dari aplikasi tersebut berada pada persentase $100 \%$. Sebagian besar penelitian yang dilakukan menerapkan kuesioner System Usability Scale (SUS) dalam melakukan pengumpulan data yang diperlukan.

Penggunaan karakteristik security dilakukan untuk mengukur sejauh mana perangkat lunak dapat mengamankan data dan informasi yang tersimpan. Gambar 12 merupakan hasil pengukuran menggunakan karakteristik security.

Made Dwi Mulyawan: Pengukuran Kualitas Sistem Informasi... 


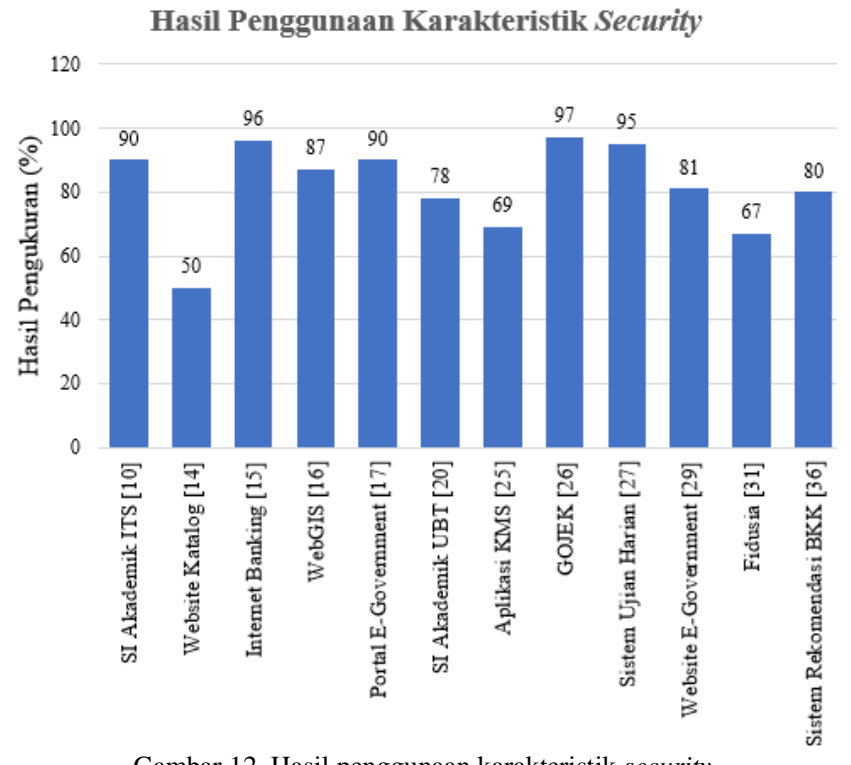

Gambar 12. Hasil penggunaan karakteristik security

Penggunaan karakteristik security setiap penelitian menunjukkan hasil dengan dengan rentang nilai 50\% sampai dengan $100 \%$. Persentase terendah pada website Katalog dikarenakan perangkat lunak yang dilakukan pengukuran tidak memenuhi persyaratan pada sub karakteristik confidentiality dan authenticity dengan hasil 0\%. Sedangkan pada aplikasi GOJEK dan Sistem Ujian Harian telah memenuhi kualitas security dengan persentase masing-masing sebesar $97 \%$ dan $100 \%$. Penilaian pada masing-masing sub karakteristik sangat mempengaruhi persentase kualitas security perangkat lunak, jika salah satu sub karakteristik memiliki hasil yang rendah maka akan mempengaruhi nilai rata-rata dari hasil akhir pengukuran.

Penggunaan karakteristik reliability dilakukan untuk mengetahui perangkat lunak dapat melakukan fungsi dalam kondisi tertentu dan jangka waktu tertentu. Adapun hasil setiap penelitian yang menggunakan karakteristik reliability dapat dilihat pada Gambar 13.

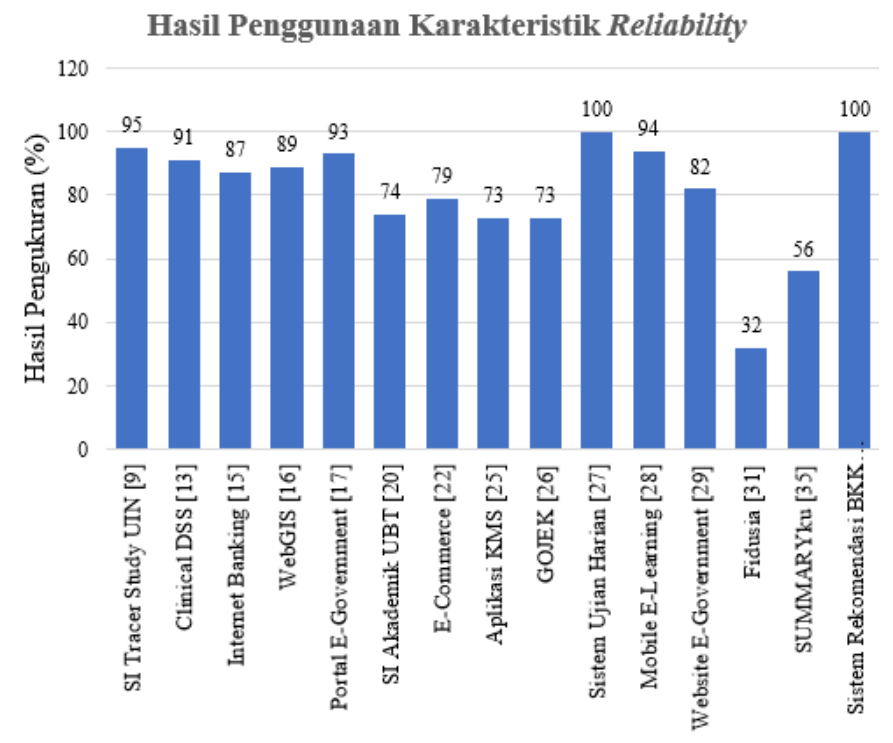

Gambar 13. Hasil penggunaan karakteristik reliability

Penggunaan karakteristik reliability setiap penelitian menunjukkan hasil dengan dengan rentang nilai $32.2 \%$ sampai dengan 100\%. Perbedaan dari masing-masing hasil pengukuran disebabkan oleh cara pengujian pada setiap penelitian. Pada Sistem Informasi Tracer Study UIN dilakukan pengujian dengan menggunakan Virtual User untuk menguji sistem pada kondisi akses yang cukup besar. Pengujian reliability menggunakan metode stress test dengan mengkondisikan 100 virtual user untuk mengakses website selama 15 menit. Selanjutnya hasil pengujian dilakukan kalkulasi dengan menggunakan perhitungan Nelson dengan persentase reliability sebesar $95 \%$.

Aplikasi Fidusia menghasilkan persentase paling rendah dibandingkan aplikasi lainnya, dimana hasil pengukuran menunjukkan bahwa aplikasi Fidusia memiliki tingkat maturity dengan kategori low yang disebabkan adanya masalah pada user experience. Dalam hal ini selain pengujian dengan mengkondisikan aksesibilitas, metode perhitungan yang digunakan memungkinkan untuk mempengaruhi tingkat akurasi dalam melakukan pengukuran, sehingga hasil yang didapatkan pada setiap penelitian akan berbeda-beda.

Penggunaan karakteristik maintainability dilakukan untuk mengetahui tingkat efektifitas dan efisiensi dari perangkat lunak dapat dimodifikasi untuk perbaikan atau menyesuaikan perubahan sistem. Hasil setiap penelitian yang menggunakan karakteristik maintainability dapat dilihat pada Gambar 14.

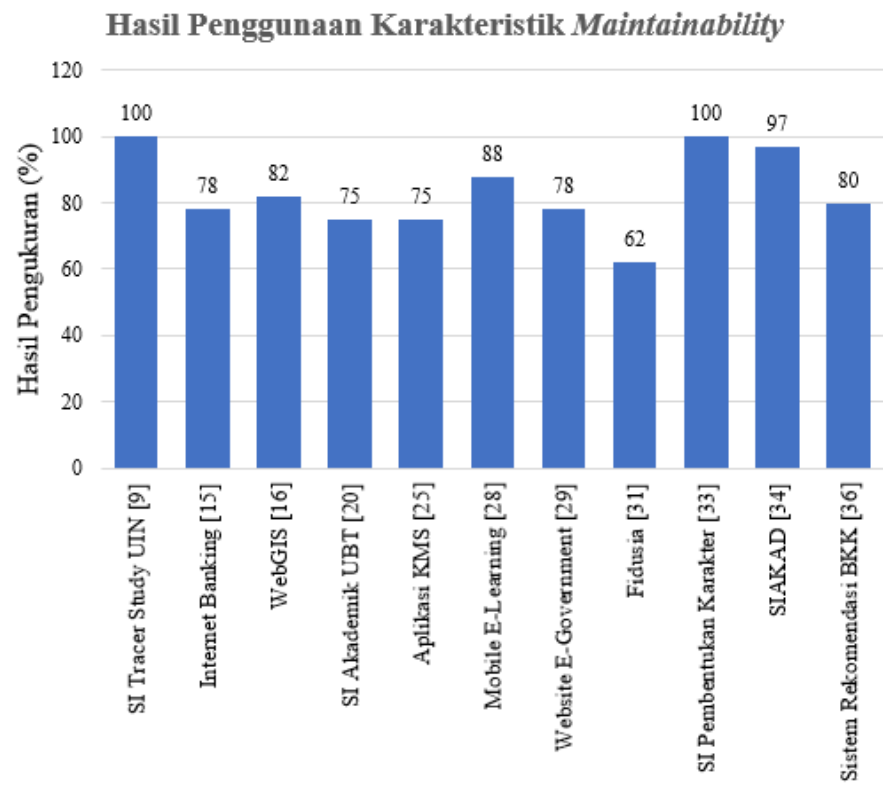

Gambar 14. Hasil penggunaan karakteristik maintainability

Penggunaan karakteristik maintainability setiap penelitian menunjukkan hasil dengan rentang nilai $62 \%$ sampai dengan $100 \%$. Perbedaan dari masing-masing hasil pengukuran disebabkan oleh cara pengujian pada setiap penelitian. Selain itu menurut Aem dan Finandhita (2017) penggunaan standarisasi bahasa pemrograman dapat mempermudah dalam proses maintenance, dimana pada aplikasi Fidusia karakteristik maintainability mendapatkan nilai sebesar $62 \%$ dengan kategori medium yang disebabkan adanya beberapa kode program yang sulit dipahami pada saat dilakukan pengukuran.

Penggunaan karakteristik portability dilakukan untuk mengetahui tingkat kegunaan dari perangkat lunak yang sama 
di lingkungan yang berbeda. Adapun hasil dari penggunaan karakteristik portability dapat dilihat pada Gambar 15 .

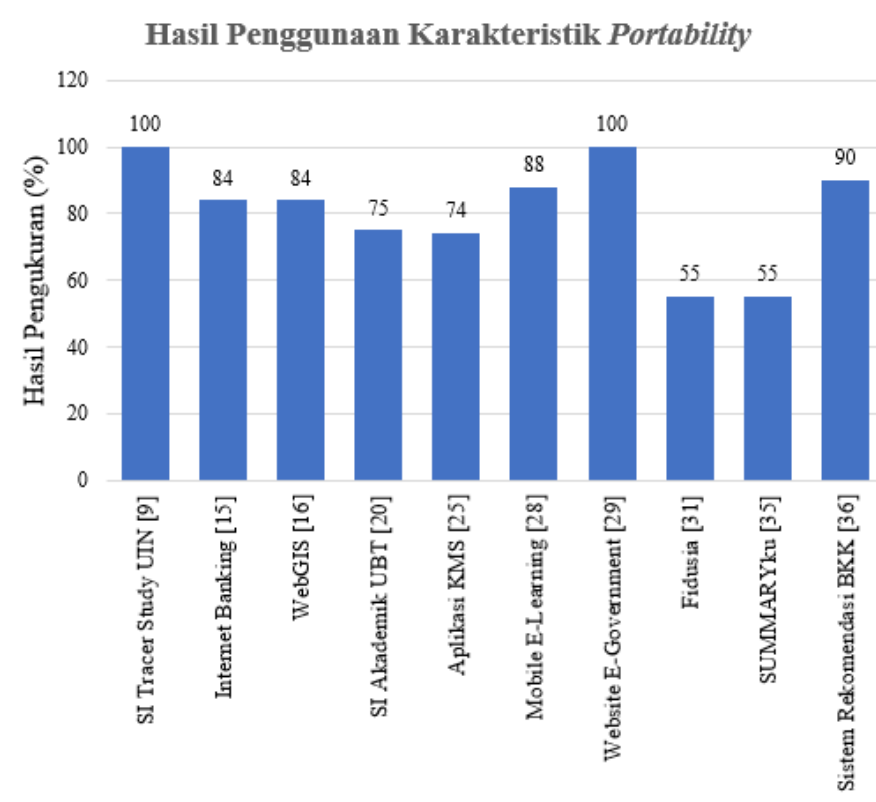

Gambar 15. Hasil penggunaan karakteristik portability

Gambar 15 merupakan hasil dari penggunaan karakteristik portability pada setiap penelitian yang menunjukkan hasil dengan rentang nilai $62 \%$ sampai dengan $100 \%$. Perbedaan dari masing-masing hasil pengukuran disebabkan oleh cara pengujian dan perhitungan hasil kuesioner yang dihasilkan. seperti pada SI Akademik Universitas Borneo Tarakan dan Aplikasi KMS Balita dan Bunda yang melakukan pengujian pada beberapa perangkat mobile, yaitu Android dan iOS sehingga memiliki nilai persentase yang sama, yaitu $75 \%$. Sedangkan pada SI Tracer Study UIN dan E-Government menggunakan metode use questionnaire dalam pengumpulan data yang diperlukan, persentase yang dihasilkan pada perangkat lunak tersebut sebesar $100 \%$.

\section{Pemilihan Perangkat Lunak}

Berdasarkan hasil telaah literature yang telah dilakukan, maka dapat dilakukan mapping terhadap pemilihan perangkat lunak yang dinilai seperti pada Tabel 3 sebagai berikut:

TABEL IIII

PENERAPAN MODEL KUALITAS PADA PERANGKAT LUNAK

\begin{tabular}{|l|l|}
\hline \multicolumn{1}{|c|}{ Jenis Perangkat Lunak } & \multicolumn{1}{c|}{ Penelitian } \\
\hline Game Online & {$[7]$} \\
\hline Mobile Application & {$[8],[25],[26],[28],[30],[32]$} \\
\hline \multirow{2}{*}{ Sistem Informasi Akademik } & {$[9],[10],[12],[20],[21],[27]$} \\
& {$[33],[34]$} \\
\hline Decision Support System & {$[11],[13],[15],[36]$} \\
\hline Website & {$[14],[18],[23],[16],[35]$} \\
\hline Sistem Informasi Pemerintah & {$[17],[24],[29]$} \\
\hline Sistem Informasi Lembaga Swasta & {$[19],[22],[31]$} \\
\hline
\end{tabular}

Tabel 3 merupakan hasil mapping terhadap pemilihan perangkat lunak sebagai objek penilaian kualitas. Jumlah pemilihan dari masing-masing perangkat lunak dapat dilihat pada Gambar 16.

Made Dwi Mulyawan: Pengukuran Kualitas Sistem Informasi...

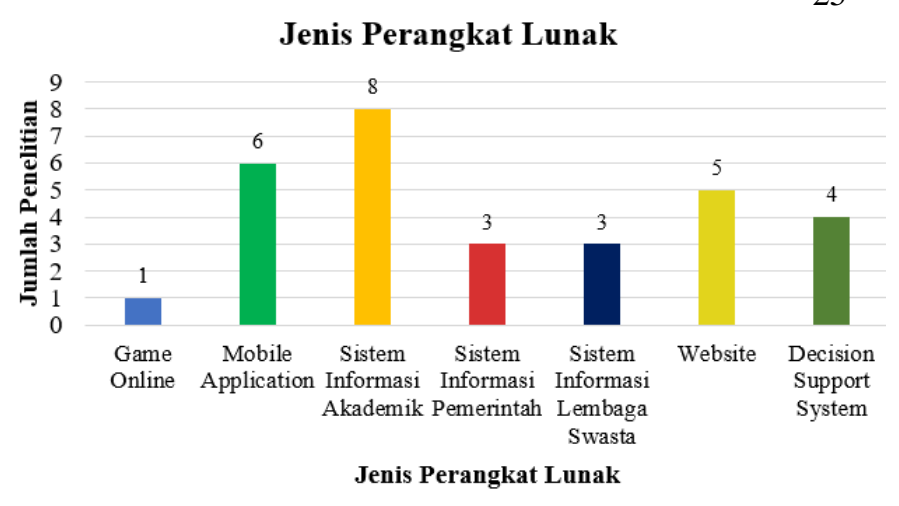

Gambar 16. Jenis perangkat lunak yang dinilai

Gambar 16 menunjukkan jumlah masing-masing perangkat lunak yang dipilih sebagai objek pengukuran kualitas. Sistem Informasi Akademik menjadi perangkat lunak yang sering digunakan sebagai objek pengukuran kualitas, dimana sistem ini digunakan pada sekolah maupun perguruan tinggi negeri atau swasta. Pengukuran pada sistem informasi akademik lebih fokus dalam aspek fungsional dan kinerja sistem, seperti yang dilakukan pada SI Tracer Study UIN, SI Akademik ITS, SI Akademik XYZ, SI Akademik UBT, SIAKAD, Sistem Ujian Harian, dan SI Pembentukan Karakter. website, decision support system dan mobile application juga telah banyak dipilih sebagai objek dalam pengukuran dari dimensi kualitas perangkat lunak dan dimensi kualitas penggunaan sistem.

Pengukuran pada mobile application dan game online lebih ditekankan pada aspek usability atau kegunaan dari sistem itu sendiri, seperti yang dilakukan pada game online DoTA dan Point Blank, AR Museum Bali, aplikasi KMS Balita dan Bunda, aplikasi GOJEK, aplikasi God Temple dan AR Tourism. Pada sistem informasi pemerintah atau lembaga swasta pengukuran kualitas perangkat lunak ditekankan pada fungsional, kegunaan, efisiensi, keamanan, dan kompatibilitas dari sistem yang digunakan dalam membantu meningkatkan proses bisnis pada instansi pemerintah/perusahaan.

Jika diurutkan berdasarkan jumlah pengguna, aplikasi AR Museum Bali, God Temple dan AR Tourism memiliki jumlah pengguna terendah karena aplikasi yang dipilih dalam pengukuran tersebut baru selesai pada tahap pengembangan. GOJEK merupakan aplikasi dengan jumlah pengguna terbanyak, yaitu sekitar 50 Juta lebih. Hal ini menjadikan pengukuran aspek usability pada aplikasi tersebut memiliki persentase tertinggi juga yaitu sebesar 95\%. Selain itu Jumlah pengguna pada game online Point Blank sejumlah 2 Juta pengguna dan DoTA berjumlah 400 Ribu pengguna, dimana rata-rata pengukuran aspek usability pada kedua game online tersebut sebesar $72 \%$ atau sudah memenuhi persyaratan kualitas penggunaan berdasarkan ISO/IEC 25010.

\section{E. Rencana Penelitian}

Beberapa penelitian telah dilakukan dalam melakukan penerapan ISO/IEC 25010 dalam melakukan pengukuran kualitas perangkat lunak. Penelitian dilakukan dengan memilih karakteristik pada software product quality model dan quality in use model sesuai dengan kebutuhan dan tingkat kepentingan aspek yang akan dilakukan penilaian pada p-ISSN:1693 - 2951; e-ISSN: 2503-2372 
perangkat lunak. Selain itu penggunaan metode tambahan seperti GQM, AHP, use questionnaire dan Fuzzy Logic juga dilakukan untuk meningkatkan akurasi pengukuran maupun pengumpulan data yang dibutuhkan dalam pengukuran kualitas. Berdasarkan hal tersebut, maka muncul sebuah rencana penelitian dengan melakukan pengukuran kualitas Sistem Informasi Monitoring Administrasi Pembangunan (Karma Simanis) yang digunakan pada Sekretariat Daerah Kota Denpasar. Tahapan dari rencana penelitian ditunjukkan pada Gambar 17.

\begin{tabular}{|c|c|c|c|c|}
\hline $\begin{array}{c}\text { Review Sistem } \\
\text { Informasi Karma } \\
\text { Simanis }\end{array}$ & \multicolumn{2}{|c|}{$\begin{array}{c}\text { Pemilihan } \\
\text { Karakteristik } \\
\text { Software Product } \\
\text { Quality Model }\end{array}$} & \multicolumn{2}{|c|}{$\begin{array}{c}\text { Perancangan Kuisioner } \\
\text { berdasarkan } \\
\text { Karakteristik Functional } \\
\text { Suitability dan Usability }\end{array}$} \\
\hline \multicolumn{2}{|c|}{$\begin{array}{c}\text { Hasil Pengukuran Kualitas } \\
\text { Kesesuaian Fungsional dan } \\
\text { Usability Sistem Informasi } \\
\text { Karma Simanis }\end{array}$} & \multicolumn{2}{|c|}{$\begin{array}{c}\text { Pengolahan Data } \\
\text { dan Analisa }\end{array}$} & $\begin{array}{l}\text { Pengumpulan } \\
\text { Data Melalui } \\
\text { Kuisioner oleh } \\
\text { Responden }\end{array}$ \\
\hline
\end{tabular}

Gambar 17. Alur rencana penelitian

Dalam rencana penelitian ini, tahapan pertama melakukan review sistem informasi Karma Simanis. Selanjutnya pada tahapan kedua dilakukan pemilihan karakteristik software product quality model untuk mengukur kualitas kesesuaian fungsional dan usability pada sistem informasi Karma Simanis. Pada tahapan ketiga dilakukan perancangan kuesioner berdasarkan karakteristik functional suitability dan usability yang dipilih. Tahapan keempat dilakukan pengumpulan data melalui kuesioner responden. Selanjutnya pada tahapan kelima dilakukan pengolahan dan analisa data untuk mendapatkan hasil pengukuran kualitas kesesuaian fungsioal dan usability pada sistem informasi Karma Simanis.

\section{KeSIMPUlan}

Berdasarkan dari hasil telaah yang dilakukan, pengukuran kualitas sistem informasi menggunakan standar kualitas ISO/IEC 25010 dapat dilakukan dengan menggunakan beberapa aspek yang ada pada standar kualitas tersebut. Pemilihan karakteristik yang digunakan dalam pengukuran dapat disesuaikan dengan aspek-aspek penting yang ada pada perangkat lunak sesuai dengan kegunaannya, sehingga proses pengukuran dapat terfokus dalam aspek yang ingin dilakukan peningkatan kualitas dalam hal evaluasi perangkat lunak.

Penggunaan metode, seperti GQM, AHP, dan Fuzzy Logic untuk melakukan pengukuran kualitas perangkat lunak juga dapat meningkatkan akurasi pengukuran kualitas. Dimana rata-rata literature menggunakan use questionnaire sebagai pengumpulan data melalui isian kuesioner dan melakukan kalkulasi dengan skala likert. Hasil dari penerapan model kualitas akan berbeda-beda dari cara pengujian, kalkulasi data, dan pemilihan perangkat lunak yang diukur kualitasnya.

\section{REFERENSI}

[1] Veljanoska, F. \& Axhiu, M., (2013). Information Systems as Support to Corporate Management. Management Information Systems, 8(4), pp. 3-9.

[2] Simanungkalit, Janry Haposan U. P. and Supardi, Satya and Bayu, Yudhantoro and Sidik, (2014) Sistem Informasi Kepegawaian. In: Konsep Dasar Sistem Informasi. Universitas Terbuka, Jakarta, pp. 1-40.
[3] ISO/IEC 25010 (2012) 'System and Software Quality Requirements and Evaluation (SQuaRE) - System and Software Quality Models', Canadian Standards Association.

[4] J. P. Miguel, D. Mauricio, and G. Rodríguez, "A Review of Software Quality Models for the Evaluation of Software Products,” Int. J. Softw. Eng. Appl., vol. 5, no. 6, pp. 31-53, Nov. 2014.

[5] Galin, D., Software Quality Assurance: From theory to implementation. London, Pearson, 2004.

[6] Suman and Wadhwa, M., "A Comparative Study of Software Quality Models," International Journal of Computer Science and Information Technologies, pp.5634-5638, 2014.

[7] Wibawa, R. C., Rochimah, S. and Anggoro, R. (2019) 'A development of quality model for online games based on ISO/IEC 25010', Proceedings of 2019 International Conference on Information and Communication Technology and Systems, ICTS 2019. IEEE, pp. 215218. doi: 10.1109/ICTS.2019.8850992.

[8] Andika, I. G. and Yanti, C. P. (2018) 'Analisis Evaluasi Aplikasi Augmented Reality Untuk Informasi Kebudayaan Bali Berdasarkan Standar ISO 25010', Jurnal RESISTOR (Rekayasa Sistem Komputer), 1(1), pp. 34-40. doi: 10.31598/jurnalresistor.v1i1.241.

[9] Anggraini, N., Putra, M. J. D. and Hakiem, N. (2019) 'Development of an Islamic Higher Education Institution Tracer Study Information System and It's Performance Analysis using ISO/IEC 25010', 2019 7th International Conference on Cyber and IT Service Management, CITSM 2019. doi: 10.1109/CITSM47753.2019.8965356.

[10] Saptarini, I., Rochimah, S. and Yuhana, U. L. (2017) 'Security Quality Measurement Framework for Academic Information System (AIS) Based on ISO/IEC 25010 Quality Model', IPTEK Journal of $\begin{array}{llll}\text { Proceedings Series, } 0(2), & \text { p. } & \end{array}$ 10.12962/j23546026.y2017i2.2310.

[11] Ben Ayed, E. et al. (2017) 'Towards a context based Evaluation Support System for Quality in Use assessment of mobile systems', 2016 IEEE International Conference on Systems, Man, and Cybernetics, SMC 2016 -Conference Proceedings, pp.4350-4355.

[12] Puspaningrum, A. S., Rochimah, S. and Akbar, R. J. (2017) 'Functional Suitability Measurement using Goal-Oriented Approach based on ISO/IEC 25010 for Academics Information System', Journal of Information Systems Engineering and Business Intelligence, 3(2), p. 68. doi: 10.20473/jisebi.3.2.68-74.

[13] Kadi, I., Idri, A. and Ouhbi, S. (2016) 'Quality evaluation of cardiac decision support systems using ISO 25010 standard', Proceedings of IEEE/ACS International Conference on Computer Systems and Applications, AICCSA, 0(1). doi: 10.1109/AICCSA.2016.7945657.

[14] Calabrese, J., Munoz, R. et al. (2018) 'Product Quality Characteristics Proposed by ISO/IEC 25010 Based on GQM-Defined Metrics', Computer Science - CACIC, 790, pp. 272-281. doi: 10.1007/978-3319-75214-3.

[15] Iqbal, H. and Babar, M. (2016) 'An Approach for Analyzing ISO / IEC 25010 Product Quality Requirements based on Fuzzy Logic and Likert Scale for Decision Support Systems', International Journal of Advanced Computer Science and Applications, 7(12), pp. 245-260. doi: 10.14569/ijacsa.2016.071232.

[16] Falih, N., Hendradjaya, B. and Sunindyo, W. D. (2017) 'Quality measurement for Web GIS using object-oriented development', Proceedings - 2016 6th International Annual Engineering Seminar, InAES 2016, pp. 144-149. doi: 10.1109/INAES.2016.7821923.

[17] Fath-Allah, A. et al. (2018) 'Towards an E-government portals quality framework based on ISO 25010', 2018 6th International Conference on Control Engineering and Information Technology, CEIT 2018, (October), pp. 25-27. doi: 10.1109/CEIT.2018.8751906.

[18] Calvo-Zamora, M., Lizano-Gallegos, J. A. and Chacon-Rivas, M. (2019) 'Quality Assessment Instrument for web Accessibility Diagnostic Tools', Proceedings - 2019 International Conference on Inclusive Technologies and Education, CONTIE 2019, pp. 218-223. doi: 10.1109/CONTIE49246.2019.00049.

[19] Martino, C. and Andry, J. F. (2020) 'Testing Aplikasi Business Activity Monitoring Pada Internet Service Provider Menggunakan Iso 25010', Jurnal Teknoinfo, 14(1), p. 35. doi: 10.33365/jti.v14i1.451.

[20] Lesmideyarti, D., Rochimah, S. and Yuhana, U. L. (2017) 'Penyusunan Dan Pengujian Metrik Operabilitas Untuk Sistem Informasi Akademik Berdasarkan ISO 25010', Inspiration: Jurnal Teknologi Informasi dan Komunikasi, 7(2), pp. 92-100. doi: 10.35585/inspir.v7i2.2442.

[21] Ghaffur, T. A. (2017) 'Analisis Kualitas Sistem Informasi Kegiatan Sekolah Berbasis Mobile Web di SMK Negeri 2 Yogyakarta', Elinvo 
(Electronics, Informatics, and Vocational Education), 2(1), pp. 94-101. doi: 10.21831/elinvo.v2i1.16426.

[22] Wattiheluw, F. H., Rochimah, S. and Fatichah, C. (2019) 'Klasifikasi Kualitas Perangkat Lunak Berdasarkan ISO/IEC 25010 Menggunakan Ahp Dan Fuzzy Mamdani Untuk Situs Web E-Commerce', JUTI: Jurnal Ilmiah Teknologi Informasi, 17(1), p. 73.

[23] Tangkudung, I., Dako, R. D. R. and Dako, A. Y. (2019) 'Evaluasi Website Menggunakan Metode ISO/IEC 25010', Seminar Nasional Teknologi, Sains dan Humaniora, 2019(November), pp. 87-107.

[24] Afiah, H., Darwiyanto, E. and Jatmiko, D. D. (2019) 'Evaluasi Kualitas Website Bandung Smart City Menggunakan ISO/IEC 25010 Qualityin-Use Model', e-Proceeding of Engineering, 6(2), pp. 8830-8837. Available at: https://smartcity.bandung.go.id.

[25] Harun, M., (2020) 'Evaluasi Kualitas Perangkat Lunak Pada Aplikasi Android KMS Balita dan Bunda', Jurnal Akrab Juara, 5(1), pp. 250260

[26] Izzatillah, M. (2019) 'Quality Measurement of Transportation Service Application Go-Jek Using Iso 25010 Quality Model', Simetris: Jurnal Teknik Mesin, Elektro dan Ilmu Komputer, 10(1), pp. 233-242. doi: 10.24176/simet.v10i1.2945.

[27] Larasati, S. S. A., Rusdianto, D. S. and Kurniawan, T. A. (2018) 'Pembangunan Sistem Ujian Harian Siswa Berbasis Web Dengan Mengacu Pada Standar Kualitas ISO 25010', Jurnal Pengembangan Teknologi Informasi dan Ilmu Komputer, 2(11), pp. 4357-4364.

[28] Razi, Pakhrur. and Putra, Amali. (2014). 'Framework Evaluasi Kualitas Aplikasi Mobile E-Learning (Framework Evaluation Quality Mobile ELearning Application)'. EKSAKTA, vol. 2, pp.17-24.

[29] Rahayuda, I. G. S. (2017) 'Evaluation of Laravel Framework on Egovernment Using ISO/IEC 25010:2011', Jurnal IPTEK-KOM (Jurnal Ilmu Pengetahuan dan Teknologi Komunikasi), 19(1), pp. 81-94.

[30] Widiantika, M., Resika, I. K. and Saindra Santyadiputra, G. (2019) 'God Temple (Geographic of Dewata Temple): Aplikasi Persebaran Pura Pada Perangkat Mobile Application Berbasis Crowdsourching', Jurnal Nasional Pendidikan Teknik Informatika (JANAPATI), 8(2), p. 166. doi: 10.23887/janapati.v8i2.17759.

[31] Aen, M. S. and Finandhita, A. (2017) 'Penilaian Kualitas Perangkat Lunak Pada Aplikasi Akta Notaris Fidusia Di CV. Fredavelop', Digital library - Perpustakaan Pusat Unikom - Knowledge Center.

[32] Ranawijaya, A., Iryanti,E., and Ferdinanda. (2020) 'Analisis Hasil Penerapan Teknologi Augmented Reality Sebagai Alternatif Media Promosi Pariwiata', Jurnal RESTI (Rekayasa Sistem dan Teknologi Informasi), vol. 4(2), pp.260-267

[33] Setiawan, H. (2017) 'Analisis Kualitas Sistem Informasi Pantauan Pembentukan Karakter Siswa Di Smk N 2 Depok Sleman', Elinvo (Electronics, Informatics, and Vocational Education), 2(1), pp. 102109. doi: 10.21831/elinvo.v2i1.16427.

[34] Rochimah, S. et al. (2017) 'Application of design patterns and quality measurement on academic information systems', Proceedings - 2017 4th International Conference on Information Technology, Computer, and Electrical Engineering, ICITACEE 2017, 2018-January, pp. 24-30. doi: 10.1109/ICITACEE.2017.8257669.

[35] Maryana, F. and Kurniawati, A. N. A. (2018) 'Quality Measurement of Automatic Text Summarization Applications Based', Journal of Software Engineering \& Intelligent Systems, vol. 3(2), pp. 200-215.

[36] Maharani, I., Budianto, A. and Ari Yuana, R. (2018) 'Sistem Rekomendasi Bursa Kerja Khusus (BKK) SMK Dengan Metode Simple Additive Weighting', Jurnal SISTEMASI, vol. 7(3), pp. 220229. doi: 10.32520/stmsi.v7i3.383.

[37] Palvia, P. et al. (2003) 'Management Information Systems Research: What's There in a Methodology?', Communications of the Association for Information Systems, 11(March). doi: 10.17705/1 cais.01116.

[38] Weber, Ron. (1999) 'Information Systems Control and Audit', London: Prentice Hall

[39] ISO/IEC JTC 1, "9126-1 Information Technology - Software Product Quality - Part 1: Quality Model.” Geneva, ISO/IEC, 2000.

[40] ISO/IEC JTC 1, "Software engineering - Software product Quality Requirements and Evaluation (SQuaRE) - Software and quality.

[41] (2020). GOJEK. http://www.gojek.com/ Accessed on 14th of May 2020

Made Dwi Mulyawan: Pengukuran Kualitas Sistem Informasi... 
\{Halaman ini sengaja di kosongkan\} 